\title{
Drivers of green bond issuance and new evidence on the "greenium"
}

\section{Kristin Ulrike Löffler ${ }^{1} \cdot$ Aleksandar Petreski $^{1}$ (D) Andreas Stephan ${ }^{1} \mathbb{D}$}

Received: 10 April 2020 / Revised: 30 October 2020 / Accepted: 2 December 2020 /

Published online: 19 February 2021

(C) The Author(s) 2021

\begin{abstract}
This paper examines whether a premium for green bonds, called "greenium", found in previous studies, exists in primary and secondary bond markets. Using a universe of about 2000 green and 180,000 non-green bonds from 650 international issuers, we apply both propensity score matching and coarsened exact matching to determine a sample of conventional bonds that is most similar to the sample of green bonds. We find that green bonds have larger issue sizes and lower rated issuers, on average, compared to conventional bonds. The estimates show that the yield for green bonds is, on average, 15-20 basis points lower than that of conventional bonds, both on primary and secondary markets, thus a "greenium" exists.
\end{abstract}

Keywords Green bonds · Matching $\cdot$ CEM $\cdot$ Yield spread

\section{Introduction}

Green bonds are any type of bond instrument where the proceeds will be exclusively applied to finance or re-finance, in part or in full, new and/or existing eligible green projects (ICMA 2018), that is, projects that help to mitigate climate change. The adoption of the Paris Climate Agreement in 2015 has spurred the development of a green bond market.

The distinction between green and conventional bonds lies in the issuers' commitment to allocate the bond proceeds to investments with environmental or climate benefits. However, the bond holder does not generally assume the corresponding environmental project risk, but usually has full recourse to the issuer's balance sheet. Therefore, fundamental risk factors pertaining to conventional and green bonds from the same issuer are presumably similar, such as, the default risk of the issuer or a liquidity premium.

Aleksandar Petreski

aleksandar.petreski@ju.se

1 Jönköping International Business School, Jönköping University, Jönköping, Sweden 
Despite strong fundamental similarities, empirical research often finds that yields between green and conventional bonds differ. For instance, Ehlers and Packer (2017) and Baker et al. (2018) have estimated a negative yield spread in the primary market, and most studies concerning yield spreads in the secondary market show that such a premium on green bonds relative to conventional bonds also persists there (Gianfrate and Peri 2019; Hachenberg and Schiereck 2018; Kapraun and Scheins 2019; Zerbib 2019). Findings related to the size of the premium range from 1 basis point (bp) (Hachenberg and Schiereck 2018) up to 69 basis points (bps) (Wulandari et al. 2018). Other studies find a positive premium in the range of 2 bps and 8 bps (Bachelet et al. 2019; Karpf and Mandel 2018).

In September 2020, the German government issued the first global twin sovereign bonds. These have the same maturity and coupon rate, but the proceeds from the green bond will be devoted to green projects based on the EU guidelines on green taxonomy. The interest from investors for the green bond was high, and, although all of the conditions of the two bonds are identical, the green version was trading at a 2 bps lower yield to maturity in the secondary market, ${ }^{1}$ indicating that investors accept a lower yield when holding a bond that has a green label. ${ }^{2}$

Two theoretical paradigms seem to offer tentative explanations for the difference in the valuation of green bonds. The first paradigm relies on the effect of pro-environmental preferences on bond yields. Accordingly, investors accept lower yields because of the "green label" of the bond. When investors engage in socially responsible investing, they are not concerned only with the payoffs from their portfolios, but assume tastes for assets as consumption goods (Fama and French 2007). Proenvironmental investors may be willing to forgo some yield to support bonds with environmental and/or climate benefits. This sacrifice of return should hold in particular for the primary market (Fatica et al. 2019; Gianfrate and Peri 2019), where the proceeds are directly used to fund a project.

The second paradigm is based on asset pricing theory to explain lower yields of green bonds relative to non-green bonds. Accordingly, green bonds may have lower risks compared to their peers (Fama 1998). For instance, the risk profiles of green and conventional bonds may differ due to the regular monitoring of the achieved environmental benefits and the actual allocation of the bond proceeds after issuance by third parties that verify the green label. In turn, this may also decrease the default probability of the bond.

Conventional bonds may carry long-term climate change risks (e.g., due to carbon tax or other future effects from physical risks) to which green bonds are not exposed. On the other hand, green bonds may also carry specific risks due to the uncertainties surrounding the development of green technologies, such as development of clean

\footnotetext{
1 The yield to maturity is retrieved from Refinitiv at the end of October 2020.

2 In this case, the proceeds of 6.5 billion $€$ from the sovereign green bond issue are used to fund governmental projects in transport, international cooperation, research and innovation, and energy and industry, among others, according to the EU environmental objectives (Federal Republic of Germany Green Bond Investor Presentation 2020).
} 
technology, or investments in the renewable energy sector. This nexus of risks associated with the green label, if priced, could reduce the greenium.

Our study makes three significant contributions. Our first contribution is introducing a more robust non-parametric matching method, known as coarsened exact matching (CEM). This methodology provides results that are less susceptible to potential bias and model dependency compared to previous research. Our study is also the first to compare results obtained from propensity score matching (PSM) and CEM for a global universe in primary and secondary bond markets. PSM is a member of the class of "Equal Percent Bias Reducing" (EPBR) matching methods, and is inferior to CEM in terms of "its ability to reduce imbalance, model dependence, estimation error, bias, variance, mean square error, and other criteria" (Iacus et al. 2012, p. 2).

Second, using a comprehensive and recent sample of bonds encompassing later stages of the market, we reexamine if the previously detected green bond premium persists in more recent years as the market of green bonds has begun to mature. Moreover, our results can be compared with existing studies, because we present the results based on unmatched, propensity-score matched, and coarsened exact matched groups of green and conventional bonds. We also refine the dual control on liquidity differences between matched green and conventional bonds introduced by Zerbib (2019). Thereby, an initial coarsening of the liquidity differences in terms of a proxy variable eliminates most liquidity bias between pairs of bonds in the matching stage. Subsequently, the empirical analysis is adjusted for two more liquidity proxies, not only controlling for the size liquidity premium, but also the risk of the bond return.

Finally, this study is, to the best of our knowledge, the first to explicitly establish and relate the yield of green bonds in the primary market to the secondary market. Using the yield to maturity (YTM) at issuance in the primary market, we control for the impact of the size of the primary market return on the secondary market ask yield.

Using the bid-ask spread as a control variable for liquidity risk, and employing issuer fixed effects, we find that the yield is significantly lower for green bonds than for comparable non-green bonds, both in the primary as well as in the secondary market. However, our results show that the greenium is more pronounced in later sample years, from 2018 to 2019. Particularly, a negative yield spread between green and conventional bonds does not begin to emerge prior to 2018, on average. Furthermore, the initial yield to maturity has a positive and significant influence on the ask yields in the secondary market. Moreover, we check the effect of the YTM and other bond characteristics on the bond return volatility in order to estimate the size of the volatility differential between green and conventional bonds. As expected, the time-to-maturity of the bond significantly affects the risk of its return. However, the bid-ask spread has no discernible impact of the yield volatility. Finally, the effect of the initial YTM and the green bond flag differs among the matching methods. While they have no significant impact on yield volatility of bonds from PSM and $\mathrm{k} 2 \mathrm{k}$ CEM, there is a significant effect on the yield risk of bonds from CEM. For the latter sample, higher YTM at issuance raises the risk on the bond return and the risk on return is higher for green bonds than for their conventional counterparts. 
The paper proceeds as follows. Section 2 provides some background information and reviews evidence on the pricing differential between green and conventional bonds in the primary and secondary markets. Section 3 describes the characteristics of the non-green and green bond universe used in this study. Following the description of the matching procedures, we outline the methods used to identify a green bond premium. Section 4, presents the results and a discussion of the findings. Section 5 contains our concluding remarks.

\section{Background and literature review}

Globally, the rapid growth of the green bond market since its inauguration in 2007 (Bank 2019), has been the result of growth drivers common across bond markets, such as macroeconomic and institutional environments, and drivers unique to the green bond market (Maltais and Nykvist 2020; Tolliver et al. 2020). For instance, drivers that initiate growth in the global green bond market pertain to the robustness of the Nationally Determined Contributions (NDCs) of countries as a response to the Paris agreement (Tolliver et al. 2020). At the country level, the institutional environment in which issuers reside may also contribute to growth. For instance, Maltais and Nykvist (2020) speculate that an institutionalized focus on environmental protection and societal awareness may have been a major driver for the rapid growth of the Swedish green bond market in past years.

For the individual bond issuer, non-financial motives, such as reputation, branding, legitimacy seeking, and "the social license to operate" (Maltais and Nykvist 2020 , p. 7), can present a decisive weight in the trade-off between green and conventional bonds, depending on the institutional environment in which the issuer resides. Closely related, the probability to issue green bonds is inversely related to the visibility of the financed project to consumers. Conversely, the level of consumers' and investors' environmental awareness (Agliardi and Agliardi 2019) and competitiveness in the "end-product market" increases the probability that an issuer will decide on a green bond relative to a non-green bond. However, extreme values in one dimension will neutralize the positive impact of another less extreme factor (Bagnoli and Watts 2020). These drivers may explain, for instance, Apple's decision to fund the recycling of used iPhones through the issuance of green bonds. Factors decisive for the issue size of conventional bonds also affect that of green bonds (Chiesa and Barua 2019). Generally, bond and issuer features, indicating enhanced payment reliability and greater return generation, positively affect the size of a green bond. These factors may include: the coupon rate, credit rating, and collateral availability of a bond, and the sector and financial health of the respective issuer. For example, Euro (EUR) denominated bond issues and those from internationally oriented issuers from emerging markets (EMs) tend to have higher issued face values than other green bonds (Chiesa and Barua 2019).

Anecdotal evidence from green bond issuers in Sweden indicates that their decision to become repeat issuers reflects previously attained pricing advantages for own green bonds. Depending on the issuer, other factors taken into consideration include a more diversified investor base, entering into a dialog with the investors, and the 
importance of non-financial motives, such as, legitimacy (Nachemson-Ekwall 2019). There are other factors that reduce the appeal of green bond issuance. These pertain to different sources of uncertainty associated with issuing a green bond for the first time, such as: establishment of reporting and work routines, collaboration within different departments and external reviews, and the uncertainty of whether the bond may reap the benefits of a green bond premium for the issuer. As a consequence, an issuer may lower its cost of capital if the credit quality is the same as with the green label (Agliardi and Agliardi 2019).

Research based on structural equations models (SEM) of the greenium in the primary market, suggests that its size is: (1) positively related to the extent of investors' and consumers' environmental awareness, and (2) negatively affected by coupon tax rates, and investors' level of risk aversion (Agliardi and Agliardi 2019). Other empirical research finds a negative yield spread between green and conventional bonds between -17 bps and -29 bps, globally (Gianfrate and Peri 2019; Fatica et al. 2019; Kapraun and Scheins 2019), although the size of the greenium seems to have declined for recent periods. Yet other studies find support for a greenium in the corporate bond sector, estimated between -24 bps and -6 bps (Gianfrate and Peri 2019; Tang and Zhang 2020). Conversely, other studies find that investors appear to behave indifferently when choosing between green and conventional bonds from the United States (US) municipal sector over the period from June 2013 to July 2018 (Larcker and Watts 2020). ${ }^{3}$ On the Chinese primary bond market, the risk premium on green bonds has an inverse relationship with an issuer's ability to signal credibility, such as the provision of third-party certification (Wang et al. 2019), or an underwriter with a high social responsibility profile (Wang et al. 2020). Furthermore, bond, issuer, and macroeconomic drivers of conventional bonds have similar effects on green bonds. These include: the bond rating, time of issuance, issue size, debt principal, nature of property rights, return on net assets of the issuer, and the prevailing market interest rate at the time of issuance. Moreover, green bonds issued by publicly listed corporations in China trade at a considerable discount to conventional bonds ( $-33 \mathrm{bps})$ (Wang et al. 2020), and contrast with the slightly positive greenium ( $0.16 \mathrm{bps}$ ) from the non-financial corporate sector over all EM countries (Fatica et al. 2019).

Agliardi and Agliardi (2019) use an SEM in their analysis of the secondary bond market, and argue that the size of the greenium is positively affected by: (1) more volatile asset prices, (2) more effective green technology that the bond finances, and (3) higher sustainability advantages, mitigating adverse effects on asset values caused by environmental damage. Additionally, lower corporate tax rates increase the greenium. For the secondary market at a worldwide scale, most studies support the existence of a negative greenium, estimated between -14 bps and -1 bps (Gianfrate and Peri 2019; Hachenberg and Schiereck 2018; Kapraun and Scheins 2019; Zerbib 2019). Conversely, Bachelet et al. (2019) argue that the greenium is positive,

\footnotetext{
${ }^{3}$ A previously reported primary market greenium of 6 bps by Baker et al. (2018) does not present a conundrum here, as the authors do not correct for tax credits associated with the Clean Renewable Energy Bonds (CREB) and Qualified Energy Conservation Bond (QECB) programs, included in the study (Larcker and Watts 2020).
} 
ranging from 2 bps to $6 \mathrm{bps}$. In relation to the sizes of the estimated yield spread on the primary market, however, those on the secondary market are around half that size. In comparison, the size of the greenium for corporate issues on the secondary market is about three times the corresponding estimate on the primary market and is over four times the secondary market greenium of all issuers. The size of the greenium corresponding to corporate issuers ( $-63 \mathrm{bps}$ ) (Nanayakkara and Colombage 2019) is at least four times higher when compared to all issuer groups. Finally, the widely differing annual estimates of the greenium for bonds listed on the London and Luxembourg stock exchanges from 2013 to 2016 (-99 bps, -48 bps, -1 bp, -69 bps) undermine assumptions of time-constant spreads between green and conventional bonds yields (Wulandari et al. 2018).

Although there is by no means a consensus, previous studies tend to confirm the existence of a negative yield spread between green and conventional bonds for global samples and most sub-samples. A notable exception is the lack of pricing discrimination between green and non-green bonds by investors in the US municipal bond market. Moreover, the estimates of the size of the greenium are most different: (1) between the primary and secondary market, (2) across geographic regions, (3) among issuers from different sectors, and (4) over years.

\section{Data and empirical approach}

\subsection{Data and descriptive findings}

The data for our study stems from the Refinitiv database and comprises all available green bonds from 2007 until October 2019, as well as the conventional bonds by the issuers of these green bonds. Tables 1,2, 3, 4 and 5 display descriptive evidence for the sample of green and conventional bonds.

Overall, the sample includes a global universe of 186,685 bonds, encompassing 184,757 non-green bonds and 1928 green bonds from 649 distinct green bond issuers. Table 1 shows the sectors of the issuers for the conventional and green bond sub-groups. Most of the bond issues are from the financial and insurance sectors. These two sectors issue $77.5 \%$ of all conventional bonds, and $43.3 \%$ of all green bonds. Fewer green bonds stem from issuers in the wholesale trade, information, health care and social assistance and other services sectors. The public administration sector has a share of $15.1 \%$ in green bonds, whereas this sector has a share of only $5.1 \%$ in conventional bonds. Likewise, the share of green bonds issued by the utilities sector $(11.9 \%)$ exceeds that of conventional bonds $(8.1 \%)$. Most likely the utilities sector is more active in green bond issuance because of the more direct and near-term materialization of environmental risks, leading to a relative surge in renewable energy projects compared to other sectors. Similarly, the real estate, rental, and leasing sector issues only $3 \%$ of all conventional bonds while it issues $11.9 \%$ of all green bonds. Also, the construction sector has a relatively high stake in green bonds $(3.4 \%)$ compared to its share in conventional bonds $(0.2 \%)$.

Table 2 presents an overview of the currency composition in the overall bond universe, and the green bond market. Overall, currencies, such as the US dollar 
Table 1 Sectors of bond issuers (Source: Refinitiv 2020)

\begin{tabular}{|c|c|c|c|}
\hline & $\mathrm{CB}(\%)$ & $\mathrm{GB}(\%)$ & Total (\%) \\
\hline Accommodation and Food Services & 0.014 & 0.156 & 0.016 \\
\hline $\begin{array}{l}\text { Administrative, Support, Waste Management, and } \\
\text { Remediation Services }\end{array}$ & 0.007 & 0.363 & 0.011 \\
\hline Agriculture, Forestry, Fishing, and Hunting & 0.029 & 0.467 & 0.033 \\
\hline Construction & 0.175 & 3.371 & 0.208 \\
\hline Educational Services & 0.011 & 0.104 & 0.012 \\
\hline Finance and Insurance & 77.5 & 43.3 & 77.2 \\
\hline Health Care and Social Assistance & 0.233 & 0.052 & 0.231 \\
\hline Information & 1.39 & 0.259 & 1.38 \\
\hline Management of Companies and Enterprises & 0.018 & 0.207 & 0.020 \\
\hline Manufacturing & 0.874 & 8.97 & 0.958 \\
\hline Mining, Quarrying, and Oil, and Gas Extraction & 0.002 & 0.052 & 0.002 \\
\hline Other Services (except Public Administration) & 1.17 & 0.622 & 1.16 \\
\hline Professional, Scientific, and Technical Services & 0.002 & 0.207 & 0.004 \\
\hline Public Authorities & 5.05 & 15.1 & 5.15 \\
\hline Real Estate, Rental, and Leasing & 3.00 & 11.8 & 3.09 \\
\hline Retail Trade & 0.129 & 0.156 & 0.129 \\
\hline Transportation and Warehousing & 1.68 & 2.65 & 1.69 \\
\hline Utilities & 8.07 & 11.9 & 8.10 \\
\hline Wholesale Trade & 0.656 & 0.259 & 0.652 \\
\hline$\cdots$ & $\cdots$ & $\ldots$ & $\ldots$ \\
\hline$N$ bonds & 184,757 & 1928 & 186,685 \\
\hline
\end{tabular}

$C B$ conventional bonds, $G B$ green bonds, 649 green bond issuer

(USD), Japanese Yen (JPY), Pound sterling (GBP), EUR, Renminbi (CNY), and the Canadian dollar (CAD) make up a smaller share in the green bond market than in the conventional bond market. Conversely, the Australian dollar (AUD), Indonesian rupiah (IDR), Indian rupee (INR), Norwegian Krona (NOK), New Zealand dollar (NZD), Swedish Krona (SEK), and Taiwan dollar (TWD) are more prevalent in the green bond market than in the conventional bond market. The share of green bonds in SEK is around four times the share in the overall bond universe. This reflects a finding by Maltais and Nykvist (2020) on issuers' and investors' interests in green bonds as a result of pressures on firms and investors to present strong sustainability profiles in Sweden. Consistent with the impact of sustainability norms on the prevalence of green bonds in a given market, almost $25 \%$ of green bonds issued in the US dollar (USD) is markedly below $40 \%$ of conventional bonds issued in USD. This may be due to the smaller role played by sustainability in the US social and political environment.

Considering the seniority composition of the total bond universe of 186,693 bonds, over $95.2 \%$ of the bonds in the universe are either unsecured (54.0\%), senior unsecured $(39.4 \%)$, or senior secured (1.8\%). Due to its share of almost 
Table 2 Currency of bond issuance (Source: Refinitiv 2020)

\begin{tabular}{llll}
\hline & CB $(\%)$ & GB $(\%)$ & Total $(\%)$ \\
\hline AUD & 3.16 & 3.63 & 3.16 \\
CAD & 3.10 & 1.81 & 3.08 \\
CHF & 1.16 & 1.09 & 1.16 \\
CNY & 8.54 & 7.93 & 8.53 \\
EUR & 25.6 & 21.3 & 25.6 \\
GBP & 4.48 & 1.19 & 4.45 \\
IDR & 0.19 & 0.78 & 0.20 \\
INR & 1.74 & 4.30 & 1.77 \\
JPY & 6.56 & 5.70 & 6.56 \\
MXN & 1.06 & 1.04 & 1.06 \\
NOK & 1.28 & 2.54 & 1.30 \\
NZD & 0.43 & 1.24 & 0.44 \\
SEK & 3.61 & 17.6 & 3.75 \\
TWD & 0.35 & 0.83 & 0.36 \\
USD & 38.7 & 29.1 & 38.6 \\
Total & 100.0 & 100.0 & 100.0 \\
$N$ Bonds & 184,764 & 1929 & 186,693 \\
\hline
\end{tabular}

$C B$ conventional bonds, $G B$ green bonds. 649 green bond issuer

Table 3 Seniority of bond issuance (Source: Refinitiv 2020)

\begin{tabular}{llll}
\hline & CB $(\%)$ & GB $(\%)$ & Total $(\%)$ \\
\hline Junior Unsecured or Junior Subordinated Unsecured & 0.184 & 1.04 & 0.193 \\
Secured & 1.13 & 0.933 & 1.13 \\
Senior Non-Preferred & 0.444 & 0.829 & 0.448 \\
Senior Preferred & 0.987 & 1.56 & 0.993 \\
Senior Secured & 1.76 & 4.98 & 1.79 \\
Senior Secured-First Lien & 0.005 & 0.518 & 0.010 \\
Senior Secured-First Mortgage & 0.050 & 0.726 & 0.057 \\
Senior Secured-First and Refunding Mortgage & 0.012 & 0.104 & 0.013 \\
Senior Secured-General and Refunding Mortgage & 0.077 & 0.052 & 0.077 \\
Senior Secured-Mortgage & 0.819 & 0.829 & 0.820 \\
Senior Secured-Second Lien & 0.001 & 0.000 & 0.001 \\
Senior Subordinated Secured & 0.002 & 0.000 & 0.002 \\
Senior Subordinated Unsecured & 0.281 & 0.156 & 0.280 \\
Senior Unsecured & 39.0 & 74.9 & 39.4 \\
Subordinated Secured & 0.004 & 0.000 & 0.004 \\
Subordinated Unsecured & 0.732 & 0.570 & 0.730 \\
Unsecured & 54.5 & 12.8 & 54.0 \\
Total & 100.0 & 100.0 & 100.0 \\
$N$ bonds & 184,764 & 1929 & 186,693 \\
\hline S & & & \\
\hline
\end{tabular}

$C B$ conventional bonds, $G B$ green bonds. 649 green bond issuer 
Table 4 Ratings of green bond issuers (Source: Refinitiv 2020)

Table 5 Purposes of green bond issuances (most frequent) (Source: Refinitiv 2020)

\begin{tabular}{llll}
\hline & CB $(\%)$ & GB $(\%)$ & Total \\
\hline High Grade & 64.1 & 53.4 & 64.0 \\
Medium Grade & 20.9 & 18.6 & 20.9 \\
Risky and Defaults & 1.97 & 2.75 & 1.98 \\
Withdrawn, not Requested & 10.4 & 6.84 & 10.4 \\
NA & 2.55 & 18.4 & 2.71 \\
Total & 100.0 & 100.0 & 100.0 \\
N Bonds & 184,764 & 1929 & 186,693 \\
\hline
\end{tabular}

$C B$ conventional bonds, $G B$ green bonds. 649 green bond issuer. $N A$ not available

\begin{tabular}{llll}
\hline Purpose & Obs & $\%$ & Cumul. \% \\
\hline Eligible Green Projects & 679 & 36.4 & 36.4 \\
Clean Transport & 341 & 18.3 & 54.6 \\
Energy Efficiency & 296 & 15.9 & 70.5 \\
Alternative Energy & 257 & 13.8 & 84.3 \\
General Purpose & 92 & 4.93 & 89.2 \\
Green Construction & 79 & 4.23 & 93.4 \\
Acquisition & 19 & 1.02 & 94.4 \\
Other & 17 & 0.911 & 95.3 \\
Environmental Protection Projects & 14 & 0.750 & 96.1 \\
Project Finance & 13 & 0.696 & 96.8 \\
General Purpose/Acquisition & 7 & 0.375 & 97.2 \\
General Purpose/Refinance & 6 & 0.321 & 97.5 \\
Working Capital & 6 & 0.321 & 97.8 \\
Refinance/Financing Expenses & 5 & 0.268 & 98.1 \\
Land Preservation & 4 & 0.214 & 98.3 \\
Sustainable Water & 4 & 0.214 & 98.5 \\
The Belt and Road Initiative & 4 & 0.214 & 98.7 \\
Water \& Sewer & 3 & 0.161 & 98.9 \\
Industrial Development & 2 & 0.107 & 99.0 \\
Merger or Acquisition & 2 & 0.107 & 99.1 \\
Renewable Energy Projects & 2 & 0.107 & 99.2 \\
.. & $\ldots$ & $\ldots$ & $\ldots$ \\
Total & 1867 & 100.0 & 100.0 \\
\hline Purpose frequncs & & &
\end{tabular}

Purpose frequencies of ca 1900 green bonds

99.97\% in the total universe, the seniority compositions in the conventional and total bond universe mirror each other. Conversely, most of the 1929 green bonds (74.9\%) are senior unsecured and a markedly smaller share of green bonds is either unsecured $(54.5 \%)$ or senior secured $(5.0 \%)$. Interestingly, $1.04 \%$ share 
of junior unsecured or junior subordinated unsecured green bonds is well above $0.18 \%$ for conventional bonds with this seniority type (Table 3 ).

Table 4 shows that around $85 \%$ of non-green and $72 \%$ of green bonds are from issuers with a high or medium rating grade, whereas nearly $13 \%$ and $25 \%$, respectively, are from issuers without a rating. Thus, it appears that green bonds belong to issuers with higher risk. Among the 649 green bond issuers analyzed in this paper, most issuers have an investment grade rating, with $64.1 \%$ of all bonds stemming from an issuer with a high grade, and $20.9 \%$ from an issuer with a medium grade. It should be noted that the share of bonds from high or medium rated issuers is $13.1 \%$ higher for non-green bonds than for green bonds. As around $2.75 \%$ of the green bonds have issuers with a risky rating compared to $1.97 \%$ of the non-green bonds. These differences again suggest that green bonds may be more risky than non-green bonds. Further, around $25.2 \%$ of the green bonds are from issuers lacking a rating, while this is the case for $13.0 \%$ of the non-green bonds (Table 4).

When we investigate the purpose of green bond issues for the 1867 green bonds in our sample, $679(36.4 \%)$ of these bonds are issued for eligible green projects, 341 bonds $(18.3 \%)$ are issued for clean transport, 296 bonds (15.9\%) are issued to improve energy efficiency, and $257(13.8 \%)$ of these bonds are issued to foster alternative energy. Further issuance purposes entail refinancing and repayment of debt contracts, working capital, social or housing projects (Table 5). As Maltais and Nykvist (2020) note, non-financial motives, including visibility or social norms, may impact an issuers decision to opt for green instead of non-green bonds.

\subsection{Matching approaches}

While the universe of issuers is the same for our samples of green and conventional bonds, Tables 1, 2, 3, 4 and 5 highlight that there are structural differences between green and conventional bond issuance. Structural differences between the two types of bonds we want to compare might particularly include: issuance volume, coupon rates, and seniority. Thus, building on previous studies (e.g., Zerbib 2019), we employ matching to create comparable samples of green and conventional bonds. We must emphasize that a matching approach can only take into account observable variables, while non-financial motives (e.g., reputation effects), cannot be controlled for as those effects are not observable. However, since our sample includes only issuers that issue both types of bonds, the reputation effects should be less important.

Previous studies have used a direct matching approach to create a pair of securities with similar properties, except for one property that becomes the focus of the investigation. Zerbib (2019) uses this method to assess the bond yield differential by matching and comparing bonds issued by the same issuer with and without a green flag. Other studies (e.g., Gianfrate and Peri 2019) use a two-step procedure required by propensity score matching (PSM). In the first step, the propensity score for green bonds is estimated conditional on a number of covariates. In the second step, green bonds (treated units) are matched with conventional bonds (control units) 
and the difference between the samples is estimated by computing the difference of the yields (outcome variable).

In our study, we employ coarsened exact matching (CEM), which is considered to be a better alternative to PSM, because CEM reduces the model dependence of the matching that is inherent in PSM (Iacus et al. 2012). CEM reduces imbalances of covariates between treated and control groups. The key property of CEM is that it is in a class of methods called Monotonic Imbalance Bounding, which bounds the maximum imbalance in some feature of the empirical distributions through an exante choice by the user.

\subsubsection{PSM}

The propensity score (the conditional treatment probability) is estimated using a probit model. ${ }^{4}$ In estimating the probability of issuance of green bond, the following control variables are employed: year of issuance, currency, issue size, time to maturity, issuer sector, callable bond, rating of issuer and seniority of the bond. Estimation results are reported in Table 6. The estimated coefficients of the year dummy variables imply an increasing likelihood of green bond issuance over time relative to the base year 2007. Relative to the base category [the Australian dollar (AUD)], except for New Zealand (NZD), the probability to issue green bonds is lower. Issuance volumes of green bonds are, on average, greater than those of conventional bonds, shown by significant and positive coefficients that are increasing for higher deciles of the size distribution of the bonds' face values. Bonds with longer maturity have a higher propensity of being issued with a green flag. There is no outstanding sector that shows a higher/lower probability to issue green bonds. Callable bonds have a higher propensity to be issued with a green label. Secured bonds show a preference of being issued with conventional terms, while green bonds with seniority have higher issuance probability.

The results from the PSM are presented in Table 7. As shown, there are a total of 1.503 green bonds on the common support, i.e., same range of propensity scores in both groups (treated and control), suggesting that common support is a necessary condition for a valid comparison of averages between both groups.

\subsubsection{CEM}

In the coarsened exact matching (CEM), after the variables are coarsened, observations are split into the resulting cross-classified strata and within each stratum exact matching on the resulting coarsened set of covariates is performed. ${ }^{5}$ Specifically, exact matching is performed on currency, sector of issuer, rating of issuer and seniority of bond, and is coarsened for the remaining variables. The overall imbalance is given by the $L_{1}$ statistic, introduced by Iacus et al. (2011) as a comprehensive

\footnotetext{
4 Stata psmatch2 command, created by Leuven and Sianesi (2003), implements full Mahalanobis matching and a variety of propensity score matching methods.

5 CEM is implemented using Stata's CEM command, described in Iacus et al. (2011).
} 
Table 6 Likelihood of green bond, marginal effects

$\operatorname{pr}($ Green Bond $)=1$

\begin{tabular}{|c|c|c|}
\hline \multicolumn{3}{|l|}{ Year of issuance } \\
\hline Year $=2007$ (Base Cat) & - & - \\
\hline Year $=2008$ & -0.0001 & {$[-0.11]$} \\
\hline Year $=2009$ & $0.0010^{*}$ & {$[1.65]$} \\
\hline Year $=2010$ & $0.0068 * * *$ & {$[6.12]$} \\
\hline Year $=2011$ & $0.0050 * * *$ & [4.99] \\
\hline Year $=2012$ & $0.0028 * * *$ & {$[3.87]$} \\
\hline Year $=2013$ & $0.0052 * * *$ & {$[6.00]$} \\
\hline Year $=2014$ & $0.0134 * * *$ & {$[11.25]$} \\
\hline Year $=2015$ & $0.0195 * * *$ & {$[15.00]$} \\
\hline Year $=2016$ & $0.0161 * * *$ & [14.08] \\
\hline Year $=2017$ & $0.0174 * * *$ & [16.34] \\
\hline Year $=2018$ & $0.0200 * * *$ & {$[18.00]$} \\
\hline Year $=2019$ & $0.0250 * * *$ & [22.03] \\
\hline Year $=2020$ & $0.0146^{* * *}$ & {$[8.63]$} \\
\hline \multicolumn{3}{|l|}{ Currency of Issuance } \\
\hline CAD & -0.0045 & {$[-0.98]$} \\
\hline $\mathrm{CHF}$ & $-0.0115^{* * *}$ & {$[-2.88]$} \\
\hline $\mathrm{CNY}$ & -0.0009 & {$[-0.26]$} \\
\hline EUR & $-0.0147 * * *$ & {$[-5.74]$} \\
\hline GBP & $-0.0203 * * *$ & {$[-7.27]$} \\
\hline IDR & $-0.0223 * * *$ & {$[-7.74]$} \\
\hline INR & $-0.0121 * * *$ & {$[-3.89]$} \\
\hline JPY & $-0.0208^{* * *}$ & {$[-8.05]$} \\
\hline $\mathrm{MXN}$ & $-0.0152 * * *$ & {$[-4.63]$} \\
\hline $\mathrm{NOK}$ & $-0.0241 * * *$ & {$[-9.31]$} \\
\hline NZD & $0.0393 * * *$ & {$[3.77]$} \\
\hline SEK & -0.0003 & {$[-0.11]$} \\
\hline TWD & -0.0069 & {$[-1.20]$} \\
\hline USD & $-0.0126^{* * *}$ & {$[-4.92]$} \\
\hline AUD (Base Cat) & - & - \\
\hline \multicolumn{3}{|l|}{ Size of issuance (deciles) } \\
\hline Decile = 1 (Base Cat) & - & - \\
\hline Decile $=2$ & $0.0028 * * *$ & [3.69] \\
\hline Decile $=3$ & $0.0039 * * *$ & {$[4.62]$} \\
\hline Decile $=4$ & 0.0008 & [1.19] \\
\hline Decile $=5$ & $0.0013 *$ & {$[1.67]$} \\
\hline Decile $=6$ & $0.0022 * * *$ & {$[2.91]$} \\
\hline Decile $=7$ & $0.0051 * * *$ & {$[5.41]$} \\
\hline Decile $=8$ & $0.0160 * * *$ & [12.98] \\
\hline Decile $=9$ & $0.0421 * * *$ & [22.59] \\
\hline Decile $=10$ & $0.0333 * * *$ & [14.79] \\
\hline
\end{tabular}


Table 6 (continued)

\begin{tabular}{|c|c|c|}
\hline \multirow[b]{2}{*}{ Time to maturity } & \multicolumn{2}{|c|}{$\operatorname{pr}($ Green Bond $)=1$} \\
\hline & $0.0005 * * *$ & [9.32] \\
\hline \multicolumn{3}{|l|}{ Issuer sector } \\
\hline Accommodation and Food Services & -0.0498 & {$[-0.50]$} \\
\hline $\begin{array}{l}\text { Administrative, Support, and Waste Management and Remedia- } \\
\text { tion Services }\end{array}$ & 0.0232 & {$[0.22]$} \\
\hline Agriculture, Forestry, Fishing, and Hunting & -0.0606 & {$[-0.62]$} \\
\hline Construction & -0.0252 & {$[-0.26]$} \\
\hline Educational Services & 0.0589 & {$[0.38]$} \\
\hline Finance and Insurance & -0.0794 & {$[-0.82]$} \\
\hline Health Care and Social Assistance & -0.0830 & {$[-0.85]$} \\
\hline Information & -0.0859 & {$[-0.88]$} \\
\hline Management of Companies and Enterprises & -0.0774 & {$[-0.80]$} \\
\hline Manufacturing & 0.0077 & {$[0.08]$} \\
\hline Other Services (Except Public Administration) & -0.0793 & {$[-0.82]$} \\
\hline Professional, Scientific, and Technical Services & 0.2304 & {$[1.09]$} \\
\hline Public Authorities & -0.0468 & {$[-0.48]$} \\
\hline Real Estate, Rental, and Leasing & -0.0576 & {$[-0.59]$} \\
\hline Retail Trade & -0.0764 & {$[-0.78]$} \\
\hline Transportation and Warehousing & -0.0667 & {$[-0.69]$} \\
\hline Utilities & -0.0556 & {$[-0.57]$} \\
\hline Wholesale Trade & -0.0875 & {$[-0.90]$} \\
\hline Mining, Quarrying, and Oil and Gas (Base Cat) & - & - \\
\hline \multicolumn{3}{|l|}{ Bond is callable } \\
\hline $\mathrm{Y}$ & $0.0035 * * *$ & {$[2.75]$} \\
\hline $\mathrm{N}$ (Base Cat) & - & - \\
\hline \multicolumn{3}{|l|}{ Issuer rating } \\
\hline High Grade & $-0.0588 * * *$ & {$[-12.75$} \\
\hline Medium Grade & $-0.0576^{* * *}$ & {$[-12.50$} \\
\hline Risky and Defaults & $-0.0568 * * *$ & {$[-11.46$} \\
\hline Withdrawn, Not Requested & $-0.0617 * * *$ & {$[-13.33$} \\
\hline NA (Base Cat) & - & - \\
\hline \multicolumn{3}{|l|}{ Seniority } \\
\hline Secured & $-0.0059 * * *$ & {$[-5.76]$} \\
\hline Senior Non-Preferred & $0.0065^{* *}$ & {$[2.02]$} \\
\hline Senior Preferred & $0.0143 * * *$ & [4.09] \\
\hline Senior Secured & $0.0066^{* * * *}$ & {$[3.94]$} \\
\hline Senior Secured-First Lien & $0.0795^{* *}$ & {$[2.11]$} \\
\hline Senior Secured—First Mortgage & 0.0050 & {$[0.98]$} \\
\hline Senior Secured-First and Refunding Mortgage & -0.0014 & {$[-0.24]$} \\
\hline Senior Secured-General and Refunding Mortgage & -0.0048 & {$[-1.06]$} \\
\hline Senior Secured-Mortgage & 0.0031 & {$[1.24]$} \\
\hline Senior Subordinated Unsecured & $-0.0043 * *$ & {$[-2.11]$} \\
\hline
\end{tabular}


Table 6 (continued)

\begin{tabular}{lll}
\hline & $\operatorname{pr}($ Green Bond $)=1$ & \\
\hline Senior Unsecured & $0.0089 * * *$ & {$[12.26]$} \\
Subordinated Unsecured & $-0.0061^{* * *}$ & {$[-4.71]$} \\
Unsecured (Base Cat) & - & - \\
Number of bonds: 129,034 & & \\
Pseudo R ${ }^{2}: 0.3516$ & & \\
Log likelihood: $-6331.927 * * *$ & & \\
\hline
\end{tabular}

Standard errors in brackets, $* p<0.10$, ** $p<0.05$, *** $p<0.01$

Table 7 Common support Propensity Score Matching

\begin{tabular}{lcc}
\hline Treatment assignment & Common support & Total \\
\hline Conventional Bonds & 56,353 & 56,353 \\
Green Bonds & 1503 & 1503 \\
Total & 57,856 & 57,856 \\
\hline
\end{tabular}

measure of global imbalance. Perfect global balance (up to coarsening) would be indicated by $L_{1}=0$, and larger values indicate a larger imbalance between the groups, where $L_{1}$ can have a maximum value of 1 . In Table 8 , we show the statistics from the $\mathrm{k} 2 \mathrm{k}$ matching. In other words, for each green bond, one most identical conventional bond is identified. The overall imbalance statistic $L_{1}$ equals 0.244 for our sample, which indicates a satisfactory global imbalance after matching, and we are able to match 836 green bonds with the same number of conventional bonds. We also perform a matching without the $\mathrm{k} 2 \mathrm{k}$ restriction, which resulted in a slightly inferior global imbalance measure of 0.248 , as weights other than 1 are assigned to bonds in the control group (Table 9).

\subsection{Empirical approach}

We perform regression analyses on the original samples and the matched samples from the two matching approaches. We specify issuer fixed effects to control for unobserved heterogeneity at the issuer level, e.g., default risk. The feature of a green bond is included as a dummy variable in the regression equation.

\section{Results and discussion}

\subsection{Yields on the primary market}

Table 10 shows that the ask yields of green bonds is negative, with -15 bps for the unmatched sample, and in the range from -16 to $-24 \mathrm{bps}$ for the matched samples. This result is in line with reported results from Ehlers and Packer (2017) and Baker et al. (2018). Estimated mean difference in spread in the sample of Ehlers and Packer 


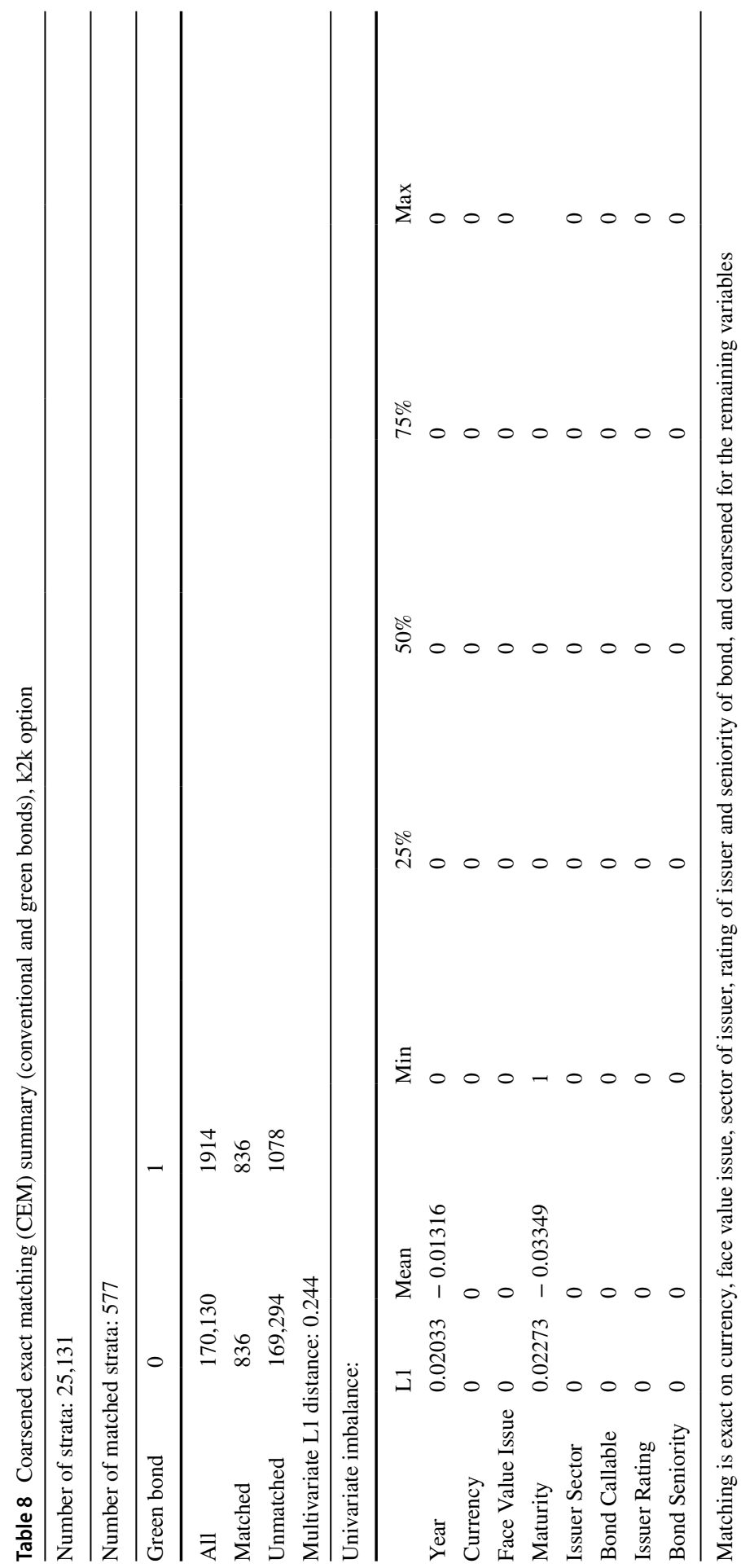


Table 9 Coarsened exact matching (CEM) Summary (conventional and green bonds), without $\mathrm{k} 2 \mathrm{k}$ option

\begin{tabular}{lcr}
\hline Number of strata: 25,131 & & \\
\hline Number of matched strata: 577 & & 1 \\
\hline Green bond & 0 & 1914 \\
\hline All & 170,130 & 947 \\
Matched & 3808 & 967 \\
Unmatched & 166,322 & \\
\hline
\end{tabular}

Multivariate L1 distance: 0.248

(2017) is around -18 bps. However, the findings are based on the sample restricted to pari passu fixed rate bonds, and to matched pairs in US and euro-denominated green bonds. Baker et al. (2018) confirm that green municipal bonds are priced at a premium, with after-tax yields at issue for green bonds about $6 \mathrm{bps}$ below yields paid by otherwise equivalent bonds. Our estimates seem reasonable as they are higher than the certification fee for the green label of the Climate Bonds Initiative, which is a flat $0.1 \mathrm{bps}$ of the issue value (Ehlers and Packer 2017), and they are not too high, for example, the highest -24 bps on a bond with a 10 -year duration, makes a yield difference of $2.4 \%$. Year dummies are significant, and their absolute value is higher than the absolute value of the negative premium. Year effects reflect the negative trend for yields after 2010.

\subsection{Yields on the secondary market}

Similar to the finding for the primary market, we estimate a significant negative green bond premium in the secondary market. This evidence confirms the results of Zerbib (2019) and Gianfrate and Peri (2019). The negative premium in the secondary market is smaller compared to the negative premium in the primary market. This result coincides with the finding in Gianfrate and Peri (2019), but our result is even more convincing, since we control for liquidity risk using the bid-ask spread as in Zerbib (2019). Gianfrate and Peri (2019) discuss whether lower premiums are the result of a convergence of yields of green bonds towards those of their conventional peers, due to a surge in the supply of green bonds along with slow demand growth. They reject this hypothesis by referring to the still existing premium in the primary market. We conjecture that smaller premiums in the secondary market compared with the primary market might be the result of the term structure when the bond is approaching its maturity. The premium on green bonds for the matched sample, after controlling for the bid-ask spread, initial yield to maturity and time to maturity, is negative and significant for all matching methods: PSM ( -15 bps), CEM ( -21 bps) and CEM k2k ( $-16 \mathrm{bps})$. The premium for the unmatched sample is positive (44 bps) but insignificant (Table 11).

We use the bid-ask spread as a liquidity proxy and as a control variable. Except for in the unmatched sample, this variable has no statistically significant effect on the yields. Conversely, Zerbib (2019) finds a significant negative effect of bid-ask spread on the yield differential between green and conventional bonds. However, 
Table 10 Yield to maturity at issuance (YTM), Primary Market

\begin{tabular}{|c|c|c|c|c|}
\hline & $\begin{array}{l}\text { (1) } \\
\text { Unmatch }\end{array}$ & $\begin{array}{l}(2) \\
\text { PSM }\end{array}$ & $\begin{array}{l}\text { (3) } \\
\text { CEM k2k }\end{array}$ & $\begin{array}{l}\text { (4) } \\
\text { CEM }\end{array}$ \\
\hline Green bond $=1$ & $\begin{array}{l}-0.151 * * * \\
{[-3.32]}\end{array}$ & $\begin{array}{l}-0.202 * * \\
{[-2.05]}\end{array}$ & $\begin{array}{l}-0.243^{* * *} \\
{[-2.69]}\end{array}$ & $\begin{array}{l}-0.158 * * \\
{[-2.21]}\end{array}$ \\
\hline Year $=2007($ Base Cat $)$ & - & - & - & - \\
\hline Year $=2008$ & $\begin{array}{l}-0.868 * * * \\
{[-17.85]}\end{array}$ & $\begin{array}{l}1.634 * * * \\
{[4.53]}\end{array}$ & - & $\begin{array}{l}4.369 * * * \\
{[8.98]}\end{array}$ \\
\hline Year $=2009$ & $\begin{array}{l}-1.725 * * * \\
{[-31.95]}\end{array}$ & $\begin{array}{l}0.716 \\
{[1.64]}\end{array}$ & - & $\begin{array}{l}-0.013 \\
{[-0.03]}\end{array}$ \\
\hline Year $=2010$ & $\begin{array}{l}-1.862 * * * \\
{[-36.33]}\end{array}$ & $\begin{array}{l}2.922 * * * \\
{[6.32]}\end{array}$ & $\begin{array}{l}3.563 * * * \\
{[4.14]}\end{array}$ & $\begin{array}{l}3.409 * * * \\
{[4.96]}\end{array}$ \\
\hline Year $=2011$ & $\begin{array}{l}-1.786 * * * \\
{[-35.33]}\end{array}$ & $\begin{array}{l}2.524 * * * \\
{[6.14]}\end{array}$ & $\begin{array}{l}2.195 * * * \\
{[3.02]}\end{array}$ & $\begin{array}{l}2.468 * * * \\
{[3.86]}\end{array}$ \\
\hline Year $=2012$ & $\begin{array}{l}-1.907 * * * \\
{[-39.82]}\end{array}$ & $\begin{array}{l}1.796 * * * \\
{[3.32]}\end{array}$ & $\begin{array}{l}2.180 * * * \\
{[3.56]}\end{array}$ & $\begin{array}{l}1.587 * * * \\
{[3.05]}\end{array}$ \\
\hline Year $=2013$ & $\begin{array}{l}-2.042 * * * \\
{[-42.43]}\end{array}$ & $\begin{array}{l}1.430 * * * \\
{[3.90]}\end{array}$ & $\begin{array}{l}1.509 * * * \\
{[4.03]}\end{array}$ & $\begin{array}{l}0.886 * \\
{[1.80]}\end{array}$ \\
\hline Year $=2014$ & $\begin{array}{l}-2.098 * * * \\
{[-43.57]}\end{array}$ & $\begin{array}{l}1.839 * * * \\
{[5.68]}\end{array}$ & $\begin{array}{l}1.628 * * * \\
{[6.47]}\end{array}$ & $\begin{array}{l}1.100 * * \\
{[2.35]}\end{array}$ \\
\hline Year $=2015$ & $\begin{array}{l}-2.246^{* * *} \\
{[-47.12]}\end{array}$ & $\begin{array}{l}1.965 * * * \\
{[6.31]}\end{array}$ & $\begin{array}{l}1.671 * * * \\
{[6.35]}\end{array}$ & $\begin{array}{l}1.121 * * \\
{[2.36]}\end{array}$ \\
\hline Year $=2016$ & $\begin{array}{l}-2.332 * * * \\
{[-49.90]}\end{array}$ & $\begin{array}{l}1.821 * * * \\
{[5.75]}\end{array}$ & $\begin{array}{l}1.680 * * * \\
{[6.84]}\end{array}$ & $\begin{array}{l}1.141 * * \\
{[2.45]}\end{array}$ \\
\hline Year $=2017$ & $\begin{array}{l}-2.128 * * * \\
{[-46.15]}\end{array}$ & $\begin{array}{l}1.794 * * * \\
{[5.85]}\end{array}$ & $\begin{array}{l}1.883^{* * * *} \\
{[8.11]}\end{array}$ & $\begin{array}{l}1.134 * * \\
{[2.46]}\end{array}$ \\
\hline Year $=2018$ & $\begin{array}{l}-1.804 * * * \\
{[-38.80]}\end{array}$ & $\begin{array}{l}1.820 * * * \\
{[6.01]}\end{array}$ & $\begin{array}{l}1.820 * * * \\
{[8.38]}\end{array}$ & $\begin{array}{l}1.189 * * * \\
{[2.59]}\end{array}$ \\
\hline Year $=2019$ & $\begin{array}{l}-1.738 * * * \\
{[-37.76]}\end{array}$ & $\begin{array}{l}1.452 * * * \\
{[4.71]}\end{array}$ & $\begin{array}{l}1.324 * * * \\
{[6.19]}\end{array}$ & $\begin{array}{l}0.692 \\
{[1.51]}\end{array}$ \\
\hline Constant & $\begin{array}{l}4.393 * * * \\
{[6.79]}\end{array}$ & $\begin{array}{l}-0.111 \\
{[-0.35]}\end{array}$ & $\begin{array}{l}-0.599 * * \\
{[-2.58]}\end{array}$ & $\begin{array}{l}0.240 \\
{[0.51]}\end{array}$ \\
\hline Obs (Bond-year) & 75,902 & 2351 & 1292 & 3,683 \\
\hline$R^{2}$ & 0.295 & 0.666 & 0.673 & 0.648 \\
\hline
\end{tabular}

Dependent variable: yield to maturity at issuance, truncated at 2.5 and $97.5 \%$ to reduce the influence of outliers. Unmatch $=$ original sample, CEM k2k $=1: 1$ matched samples, robust $t$ statistics in brackets. * $p<0.10, * * p<0.05, * * * p<0.01$

Wulandari et al. (2018) show that the bid-ask spread does not influence yield spreads (over risk-free rate) for green bonds, while for the conventional bonds yield spread increases when the bid-ask spread goes up.

The effect of bond maturity on yields is only significant for the unmatched sample, with a positive coefficient. For the matched samples, the influence of 
Table 11 Ask yield, Secondary Market

\begin{tabular}{|c|c|c|c|c|}
\hline & (1) & (2) & (3) & (4) \\
\hline & Unmatch & PSM & CEM k2k & CEM \\
\hline \multirow[t]{2}{*}{ Green Bond=1 } & 0.043 & $-0.152 * *$ & $-0.216^{* *}$ & $-0.156^{* *}$ \\
\hline & [1.03] & {$[-2.44]$} & {$[-2.44]$} & {$[-2.23]$} \\
\hline \multirow[t]{2}{*}{ Bid-ask Spread } & $0.277 * *$ & 0.170 & 0.243 & -0.286 \\
\hline & {$[2.20]$} & {$[1.02]$} & {$[0.65]$} & {$[-1.43]$} \\
\hline \multirow[t]{2}{*}{ YTM at Issuance } & $0.702 * * *$ & $0.846^{* * *}$ & $0.840 * * *$ & $0.943 * * *$ \\
\hline & {$[25.84]$} & {$[21.20]$} & [13.04] & [19.01] \\
\hline \multirow[t]{2}{*}{ Time to Maturity } & $0.009^{*}$ & -0.005 & 0.006 & -0.011 \\
\hline & [1.89] & {$[-0.80]$} & {$[0.53]$} & {$[-1.18]$} \\
\hline \multirow[t]{2}{*}{ Year $=2012$} & -0.761 & -0.854 & - & - \\
\hline & {$[-1.07]$} & {$[-0.89]$} & & \\
\hline \multirow[t]{2}{*}{ Year $=2013$} & -0.379 & -0.532 & 0.492 & 0.502 \\
\hline & {$[-0.61]$} & {$[-0.59]$} & {$[0.69]$} & {$[0.48]$} \\
\hline \multirow[t]{2}{*}{ Year $=2014$} & -0.775 & -0.826 & 0.311 & 0.544 \\
\hline & {$[-1.25]$} & {$[-0.97]$} & {$[0.52]$} & {$[0.66]$} \\
\hline \multirow[t]{2}{*}{ Year $=2015$} & $-1.304 * *$ & $-1.487 *$ & 0.278 & 0.433 \\
\hline & {$[-2.09]$} & {$[-1.73]$} & {$[0.44]$} & {$[0.52]$} \\
\hline \multirow[t]{2}{*}{ Year $=2016$} & $-1.364 * *$ & -1.361 & -0.084 & 0.171 \\
\hline & {$[-2.20]$} & {$[-1.60]$} & {$[-0.14]$} & {$[0.21]$} \\
\hline \multirow[t]{2}{*}{ Year $=2017$} & -0.974 & -0.871 & 0.100 & 0.390 \\
\hline & {$[-1.58]$} & {$[-1.02]$} & {$[0.17]$} & {$[0.48]$} \\
\hline \multirow[t]{2}{*}{ Year $=2018$} & -0.697 & -0.627 & 0.319 & 0.577 \\
\hline & {$[-1.13]$} & {$[-0.74]$} & {$[0.53]$} & {$[0.71]$} \\
\hline \multirow[t]{2}{*}{ Year $=2019$} & $-1.169 *$ & -1.079 & -0.197 & 0.104 \\
\hline & {$[-1.89]$} & {$[-1.27]$} & {$[-0.33]$} & {$[0.13]$} \\
\hline \multirow[t]{2}{*}{ Constant } & $1.059 *$ & 1.005 & 0.703 & -0.017 \\
\hline & [1.69] & {$[1.17]$} & {$[1.04]$} & {$[-0.02]$} \\
\hline Issuer FE & Yes & Yes & Yes & Yes \\
\hline Obs (Bond-year Weighted) & 3966 & 3225 & 1271 & 2292 \\
\hline$R^{2}$ & 0.869 & 0.897 & 0.883 & 0.899 \\
\hline
\end{tabular}

Dependent variable: annual ask yield, truncated at 2.5 and $97.5 \%$ to reduce the influence of outliers. Bidask spread and time to maturity are winsorized at 2.5 and $97.5 \%$. Unmatch $=$ original sample, CEM k2k $=1: 1$ matched samples. Robust standard errors in brackets. $* p<0.10, * * p<0.05, * * * p<0.01$

bond maturity on yields is not significant. In Karpf and Mandel (2018), the yield increases with risk, measured via days to maturity (dtm). The green bond premium, in contrast, does not appear to be significantly impacted by the maturity of the bond (Zerbib 2019). Furthermore, in Wulandari et al. (2018) the maturity coefficient has a negative effect on the yield spread of green bonds and a positive for conventional bonds. In this context, Fons (1994) finds that lower rated (smaller, younger, more heavily leveraged) issuers tend to have wider credit spreads that narrow with maturity. Higher rated (more mature, stable) firms tend 
Table 12 Ask yield, Secondary Market—subsamples

\begin{tabular}{|c|c|c|c|c|}
\hline & \multicolumn{2}{|l|}{ Until 2017} & \multicolumn{2}{|l|}{ After 2017} \\
\hline & (1) & (2) & (3) & (4) \\
\hline & PSM & CEM & PSM & CEM \\
\hline \multirow[t]{2}{*}{ Green Bond=1 } & 0.045 & -0.024 & $-0.233 * * *$ & $-0.177 * *$ \\
\hline & {$[0.41]$} & {$[-0.20]$} & {$[-2.84]$} & {$[-2.07]$} \\
\hline \multirow[t]{2}{*}{ Bid-ask spread } & 0.281 & 0.057 & 0.119 & -0.419 \\
\hline & {$[1.06]$} & {$[0.15]$} & {$[0.40]$} & {$[-1.46]$} \\
\hline \multirow[t]{2}{*}{ YTM at Issuance } & $0.848 * * *$ & $0.959 * * *$ & $0.832 * * *$ & $0.947 * * *$ \\
\hline & {$[10.76]$} & {$[10.98]$} & {$[18.01]$} & {$[15.90]$} \\
\hline \multirow[t]{2}{*}{ Time to Maturity } & 0.016 & 0.031 & $-0.017^{*}$ & $-0.026^{* *}$ \\
\hline & {$[1.36]$} & {$[1.03]$} & {$[-1.74]$} & {$[-2.49]$} \\
\hline Year FE & yes & yes & yes & yes \\
\hline Issuer FE & yes & yes & yes & yes \\
\hline \multirow[t]{2}{*}{ Constant } & $8.003^{* * *}$ & -1.044 & $0.645^{* * *}$ & $0.836^{* * *}$ \\
\hline & {$[8.39]$} & {$[-1.25]$} & {$[4.60]$} & {$[5.83]$} \\
\hline Obs (Bond-year Weighted) & 1122 & 721 & 2103 & 1571 \\
\hline$R^{2}$ & 0.890 & 0.886 & 0.925 & 0.927 \\
\hline
\end{tabular}

Dependent variable: annual ask yield, truncated at 2.5 and $97.5 \%$ to reduce influence of outliers. Bid-ask spread and time to maturity are winsorized at 2.5 and $97.5 \%$. Unmatch $=$ original sample, CEM $\mathrm{k} 2 \mathrm{k}=$ 1:1 matched samples. Robust standard errors in brackets. * $p<0.10, * * p<0.05, * * * p<0.01$

to have narrower credit spreads that widen with maturity. As argued by Campbell and Taksler (2003), a positive relationship between maturity and yield spreads is usually expected for investment grade bonds.

We test the effect of underpricing by including the original yield at issuance as a control variable in the regressions that address the secondary market yield. We interpret a coefficient of less than 1 as evidence for a tightening of yields, since it implies that secondary market yields are on average lower than primary market yields.

As a further test we split our sample into a period before and after 2018. The estimation results are shown in Table 12. Interestingly, the result for the negative spread of green bonds compared to their matched controls is mainly driven by the most recent years 2018 and 2019. An analysis of the years before 2018 does not reveal a significant relationship. This result might indicate that the green premium is timevarying. The expectations hypothesis $(\mathrm{EH})$ used in term structure theory suggests that risk premia (expected excess returns) on bonds are constant over time. However, there is considerable evidence against this hypothesis, so it is important to allow for the possibility that risk premia are time-varying (Campbell et al. 2009). There is no reason to believe that green premium (as a part of the risk premium) would not be time-varying. Still, we do not have a sufficiently long time-series of bonds to test this in more detail.

In addition, we test whether the volatility of yields is different for green and conventional bonds. Results are displayed in Table 13. For the PSM and the k2k CEM 
Table 13 Ask yield volatility annualized, Secondary Market

\begin{tabular}{|c|c|c|c|c|}
\hline & $\begin{array}{l}\text { (1) } \\
\text { Unmatch }\end{array}$ & $\begin{array}{l}(2) \\
\text { PSM }\end{array}$ & $\begin{array}{l}\text { (3) } \\
\text { CEM k2k }\end{array}$ & $\begin{array}{l}\text { (4) } \\
\text { CEM }\end{array}$ \\
\hline Green Bond=1 & $\begin{array}{l}-0.031 \\
{[-1.48]}\end{array}$ & $\begin{array}{l}0.023 \\
{[1.02]}\end{array}$ & $\begin{array}{l}0.055 \\
{[1.54]}\end{array}$ & $\begin{array}{l}0.054 * * * \\
{[2.67]}\end{array}$ \\
\hline Bid-ask Spread & $\begin{array}{l}-0.001 \\
{[-0.01]}\end{array}$ & $\begin{array}{l}0.021 \\
{[0.31]}\end{array}$ & $\begin{array}{l}0.196 \\
{[1.28]}\end{array}$ & $\begin{array}{l}0.148 \\
{[1.23]}\end{array}$ \\
\hline YTM at Issuance & $\begin{array}{l}-0.008 \\
{[-0.93]}\end{array}$ & $\begin{array}{l}-0.011 \\
{[-1.25]}\end{array}$ & $\begin{array}{l}0.013 \\
{[1.03]}\end{array}$ & $\begin{array}{l}0.020 * * \\
{[2.10]}\end{array}$ \\
\hline Time to Maturity & $\begin{array}{l}-0.016^{* * *} \\
{[-6.48]}\end{array}$ & $\begin{array}{l}-0.018^{* * *} \\
{[-6.12]}\end{array}$ & $\begin{array}{l}-0.008^{* *} \\
{[-2.39]}\end{array}$ & $\begin{array}{l}-0.008 * * \\
{[-2.52]}\end{array}$ \\
\hline Year $=2012$ & $\begin{array}{l}-0.517 * * * \\
{[-3.76]}\end{array}$ & $\begin{array}{l}-0.516^{* * *} \\
{[-3.90]}\end{array}$ & - & - \\
\hline Year $=2013$ & $\begin{array}{l}-0.463^{* * *} \\
{[-3.32]}\end{array}$ & $\begin{array}{l}-0.461 * * * \\
{[-3.45]}\end{array}$ & $\begin{array}{l}0.118^{* *} \\
{[2.09]}\end{array}$ & $\begin{array}{l}0.094 * * \\
{[1.96]}\end{array}$ \\
\hline Year $=2014$ & $\begin{array}{l}-0.428 * * * \\
{[-2.79]}\end{array}$ & $\begin{array}{l}-0.411 * * * \\
{[-2.68]}\end{array}$ & $\begin{array}{l}0.373 * * * \\
{[2.88]}\end{array}$ & $\begin{array}{l}0.325 * * * \\
{[2.79]}\end{array}$ \\
\hline Year $=2015$ & $\begin{array}{l}-0.611 * * * \\
{[-4.49]}\end{array}$ & $\begin{array}{l}-0.619 * * * \\
{[-4.75]}\end{array}$ & $\begin{array}{l}0.116^{* *} \\
{[2.32]}\end{array}$ & $\begin{array}{l}0.065 \\
{[1.45]}\end{array}$ \\
\hline Year $=2016$ & $\begin{array}{l}-0.317 * * \\
{[-2.33]}\end{array}$ & $\begin{array}{l}-0.307 * * \\
{[-2.37]}\end{array}$ & $\begin{array}{l}0.201 * * * \\
{[3.76]}\end{array}$ & $\begin{array}{l}0.199 * * * \\
{[4.75]}\end{array}$ \\
\hline Year $=2017$ & $\begin{array}{l}-0.595 * * * \\
{[-4.41]}\end{array}$ & $\begin{array}{l}-0.589 * * * \\
{[-4.56]}\end{array}$ & $\begin{array}{l}0.127 * * \\
{[2.17]}\end{array}$ & $\begin{array}{l}0.084 * \\
{[1.89]}\end{array}$ \\
\hline Year $=2018$ & $\begin{array}{l}-0.502 * * * \\
{[-3.70]}\end{array}$ & $\begin{array}{l}-0.490 * * * \\
{[-3.78]}\end{array}$ & $\begin{array}{l}0.157 * * \\
{[2.33]}\end{array}$ & $\begin{array}{l}0.151 * * * \\
{[3.06]}\end{array}$ \\
\hline Year $=2019$ & $\begin{array}{l}-0.399 * * * \\
{[-2.94]}\end{array}$ & $\begin{array}{l}-0.391 * * * \\
{[-3.01]}\end{array}$ & $\begin{array}{l}0.286^{* * * *} \\
{[4.39]}\end{array}$ & $\begin{array}{l}0.251 * * * \\
{[5.22]}\end{array}$ \\
\hline Constant & $\begin{array}{l}0.698 * * * \\
{[4.77]}\end{array}$ & $\begin{array}{l}0.642 * * * \\
{[4.52]}\end{array}$ & $\begin{array}{l}-0.320 * * * \\
{[-3.16]}\end{array}$ & $\begin{array}{l}-0.223 * * * \\
{[-2.70]}\end{array}$ \\
\hline Issuer FE & Yes & Yes & Yes & Yes \\
\hline Obs (Bond-year Weighted) & 2667 & 2524 & 1129 & 1345 \\
\hline$R^{2}$ & 0.517 & 0.530 & 0.425 & 0.456 \\
\hline
\end{tabular}

Dependent variable: annualized volatility of ask yield, truncated at 2.5 and $97.5 \%$ to reduce influence of outliers. Bid-ask spread and time to maturity are winsorized at 2.5 and $97.5 \%$. Unmatch $=$ original sample, CEM k2k = 1:1 matched samples. Robust standard errors in brackets. ${ }^{*} p<0.10$, ** $p<0.05$, $* * * p<0.01$

matched samples we do not find a significant difference between green and conventional bonds. However, for the last model based on the CEM sample, we see that the volatility of yields is significantly higher for green bonds. While one should distinguish between idiosyncratic and systematic risk and their impact on expected yields, in terms of the volatility of yields these results imply that green bonds may not be less risky than their conventional counterparts. Again, this confirms the notion that it is the preference for a "green label", rather than lower risk that explains lower 
yields of green bonds. Indeed, Greenwood and Vayanos (2014)'s model as the representative example of the demand/supply paradigm in term structure theory, predicts that an increase in supply should raise bond yields and expected returns, holding the short rate constant. In our context of green bonds this would mean that for a fixed supply of green bonds, an increase in demand for bonds with a "green label" should decrease the yields of green bonds and expected returns.

Also, in the last model using CEM matching, YTM at issuance has a positive influence on the yield volatility. This result is in line with Viceira (2012), who empirically proves the ability of the short rate to forecast the bond return volatility positively at all horizons. In this study, realized log volatility is regressed onto a constant, its own lagged value, the log short rate and the yield spread.

We perform a robustness test of the effect of ask yield volatility on ask yields. The results show that yields are not related to yield volatility. This result is similar to Zerbib (2019) and thus cannot be explained by this risk measure. As the main results remained unchanged this result table is not presented, but is available upon request.

\section{Conclusions}

Green bond markets have shown high growth rates in recent years, and continue to grow. In this paper, we investigate the characteristics of green bond issuances, and estimate whether green bonds offer lower or higher yields compared to similar non-green bonds from the same issuers. We analyze a universe of about 2000 green bonds and identify a control group of non-green bonds from a sample of 180,000 conventional bonds.

The descriptive statistics of our paper show that most green bonds fund renewable energy, energy efficiency, and clean transport projects. While green bond issuers are from many sectors, those from finance and insurance, utilities, construction, and real estate are over represented. Interestingly, green bonds are more likely to be senior unsecured debt bonds, and issuance amounts are slightly larger than those of conventional bonds. Green bond issuers are more likely to be not rated. In relative terms, we find that most green bond issuances are nominated in either EUR, USD or SEK, and, relative to their size, Swedish issuers are over represented in the green bond market.

In our comparison of the yields of green bonds with those of conventional bonds, we follow previous literature by matching the sample of green bonds with conventional bonds that have similar characteristics, both in terms of issuer structure (rating, sector), issuance volume, bond seniority and time to maturity. We use both propensity score matching and coarsened exact matching to determine several comparison groups. In contrast to previous studies, however, we analyze initial yields at issuance, as well as yields achieved on secondary markets. The secondary market yield has not been considered in previous studies.

The estimation results show that green bond yields are a statistically significant 15-20 bps lower than those of comparable conventional bonds, which holds both for the primary and the secondary market. This spread has been labeled as a greenium in the literature. However, we find that the result for the secondary market in our 
sample is driven by the years 2018 and 2019, but does not hold for the earlier years of our sample. It is worth noting that we control for unobserved issuer heterogeneity in our regressions by using fixed effects and also include year effects.

There are two potential explanations for our finding that green bonds have a lower yield relative to their peers. From an asset pricing perspective, the fact that green bonds have lower underlying risks might explain their lower yields. Another explanation suggested in the literature is that institutional investors are willing to pay a higher price for the bond's "green label" because they have a pro-environmental preference. Since we find that issuers of green bond are less likely to have any credit rating, and that green bonds are more likely to be senior unsecured debt, the second explanation appears to be more plausible. This is also supported by the finding that the volatility of yields of green bonds is not lower, and potentially even higher, than that of their conventional counterparts. Furthermore, we cannot confirm that the lower yields of green bonds in the primary market is a significant driver for lower yields in the secondary market.

Future research might explore the risks of green bonds in more detail, and distinguish between idiosyncratic and systematic risks. Besides liquidity risk, which has been studied before, the impact of environmental risk on green bond yields would be another topic to investigate. While the time span is currently still too short for such an analysis, a study on the default risk of green bonds is another promising avenue for future studies.

Funding Open access funding provided by Jönköping University.

Open Access This article is licensed under a Creative Commons Attribution 4.0 International License, which permits use, sharing, adaptation, distribution and reproduction in any medium or format, as long as you give appropriate credit to the original author(s) and the source, provide a link to the Creative Commons licence, and indicate if changes were made. The images or other third party material in this article are included in the article's Creative Commons licence, unless indicated otherwise in a credit line to the material. If material is not included in the article's Creative Commons licence and your intended use is not permitted by statutory regulation or exceeds the permitted use, you will need to obtain permission directly from the copyright holder. To view a copy of this licence, visit http://creativecommons.org/licen ses/by/4.0/.

\section{References}

Agliardi, E., \& Agliardi, R. (2019). Financing environmentally-sustainable projects with green bonds. Environment and Development Economics, 24(6), 608-623. https://doi.org/10.1017/S1355770X19000020.

Bachelet, M., Becchetti, L., \& Manfredonia, S. (2019). The green bonds premium puzzle: The role of issuer characteristics and third-party verification. Sustainability, 11(4), 1-22. https://doi.org/10.3390/su110 41098.

Bagnoli, M., \& Watts, S. G. (2020). On the corporate use of green bonds. Journal of Economics \& Management Strategy, 29(1), 187-209. https://doi.org/10.1111/jems.12331.

Baker, M., Bergstresser, D., Serafeim, G., \& Wurgler, J. (2018). Financing the response to climate change: The pricing and ownership of u.s. green bonds (Working Paper No. 25194). National Bureau of Economic Research. https://doi.org/10.3386/w25194.

Bank, E. I. (2019). EIB climate awareness bonds. https://www.eib.org/en/investor_relations/cab/. Accessed 24 Dec 2020.

Campbell, J. Y., Shiller, R. J., \& Viceira, L. M. (2009). Understanding inflation-indexed bondmarkets. Brookings Papers on Economic Activity, 2009, 79-120. 
Campbell, J. Y., \& Taksler, G. B. (2003). Equity volatility and corporate bond yields. The Journal of Finance, 58(6), 2321-2350. https://doi.org/10.1046/j.1540-6261.2003.00607.x.

Chiesa, M., \& Barua, S. (2019). The surge of impact borrowing: The magnitude and determinants of green bond supply and its heterogeneity across markets. Journal of Sustainable Finance \& Investment, 9(2), 138-161. https://doi.org/10.1080/20430795.2018.1550993.

Ehlers, T. \& Packer, F. (2017). Green bond finance and certification (BIS Quarterly Review No. 3). Bank for International Settlements. https://www.bis.org/publ/qtrpdf/r_qt1709h.htm. Accessed 24 Dec 2020.

Fama, E. F. (1998). Determining the number of priced state variables in the ICAPM. The Journal of Financial and Quantitative Analysis, 33(2), 217-231.

Fama, E. F., \& French, K. R. (2007). Disagreement, tastes, and asset prices. Journal of Financial Economics, 83(3), 667-689. https://doi.org/10.1016/j.jfineco.2006.01.003.

Fatica, S., Panzica, R., \& Rancan, M. (2019). The pricing of green bonds: Are financial institutions special? (Tech. rep. No. 7). https://doi.org/10.2760/496913

Federal Republic of Germany Green Bond Investor Presentation. (2020). https://www.deutsche-finanzagen tur.de/de/institutionelle-investoren/bundeswertpapiere/gruene-bundeswertpapiere/pm-green-bund/. Accessed 24 Dec 2020.

Fons, J. S. (1994). Using default rates to model the term structure of credit risk. Financial Analysts Journal, 50(5), 25-32.

Gianfrate, G., \& Peri, M. (2019). The green advantage: Exploring the convenience of issuing green bonds. Journal of Cleaner Production, 219, 127-135. https://doi.org/10.1016/j.jclepro.2019.02.022.

Greenwood, R., \& Vayanos, D. (2014). Bond supply and excess bond returns. The Review of Financial Studies, 27(3), 663-713.

Hachenberg, B., \& Schiereck, D. (2018). Are green bonds priced differently from conventional bonds? Journal of Asset Management, 19, 371-383. https://doi.org/10.1057/s41260-018-0088-5.

Iacus, S. M., King, G., \& Porro, G. (2011). Multivariate matching methods that are monotonie imbalance bounding. Journal of the American Statistical Association, 106(493), 345-361.

Iacus, S. M., King, G., \& Porro, G. (2012). Causal inference without balance checking: Coarsened exact matching. Political Analysis, 20(1), 1-24. https://doi.org/10.1093/pan/mpr013.

ICMA. (2018). Green bond principles. https:/www.icmagroup.org/green-social-and-sustainability-bonds/ green-bond-principles-gbp/. Accessed 24 Dec 2020.

Kapraun, J. \& Scheins, C. (2019). (in)-credibly green: Which bonds trade at a green bond premium? Working Paper. https://ssrn.com/abstract=3347337. Accessed 24 Dec 2020.

Karpf, A., \& Mandel, A. (2018). The changing value of the 'green' label on the US municipal bond market. Nature Climate Change, 8, 161-168. https://doi.org/10.1038/s41558-017-0062-0.

Larcker, D. F., \& Watts, E. M. (2020). Where's the greenium? Journal of Accounting and Economics,. https ://doi.org/10.1016/j.jacceco.2020.101312.

Leuven, E., \& Sianesi, B. (2003). Psmatch2: Stata module to perform full Mahalanobis and Propensity Score Matching, Common Support Graphing, and Covariate Imbalance Testing. Boston College Department of Economics: Statistical Software Components.

Maltais, A., \& Nykvist, B. (2020). Understanding the role of green bonds in advancing sustainability. Journal of Sustainable Finance \& Investment, https://doi.org/10.1080/20430795.2020.1724864.

Nachemson-Ekwall, S. (2019). A Swedish market for sustainability-related and socially labelled bonds. Institutional investors as drivers (SSE Working Paper Series in Business Administration No. 2019:3). Stockholm School of Economics.

Nanayakkara, M., \& Colombage, S. (2019). Do investors in green bond market pay a premium? Global evidence. Applied Economics, 51(40), 4425-4437. https://doi.org/10.1080/00036846.2019.1591611.

Refinitiv. (2020). TRBC Sector Classification. Available at: https://www.refinitiv.com/en/financial-data/ indices/trbc-business-classification. Accessed 24 Dec 2020.

Tang, D. Y., \& Zhang, Y. (2020). Do shareholders benefit from green bonds? Environmental, social, and governance issues: Emerging markets and beyond. Journal of Corporate Finance, 61, 101427. https://doi. org/10.1016/j.jcorpfin.2018.12.001.

Tolliver, C., Keeley, A. R., \& Managi, S. (2020). Drivers of green bond market growth: The importance of nationally determined contributions to the Paris agreement and implications for sustainability. Journal of Cleaner Production, 244, 1-14. https://doi.org/10.1016/j.jclepro.2019.118643.

Viceira, L.M. (2012). Bond risk, bond return volatility, and the termstructure of interest rates. International Journal of Forecasting, 28(1), 97-117. Special Section 1: The Predictability of Financial Markets Special Section 2: Credit Risk Modelling and Forecasting. https://doi.org/10.1016/j.ijforecast.2011.02.018. 
Wang, J., Chen, X., Li, X., Yu, J., \& Zhong, R. (2020). The market reaction to green bond issuance: Evidence from china. Pacific-Basin Finance Journal, 60, 101294. https://doi.org/10.1016/j.pacfin.2020.101294.

Wang, Q., Zhou, Y., Luo, L., \& Ji, J. (2019). Research on the factors affecting the risk premium of China's green bond issuance. Sustainability,. https://doi.org/10.3390/su11226394.

Wulandari, F., Schäfer, D., Stephan, A., \& Su, C. (2018). The impact of liquidity risk on the yield spread of green bonds. Finance Research Letters, 27, 53-59. https://doi.org/10.1016/j.frl.2018.02.025.

Zerbib, O. (2019). The effect of pro environmental preferences on bond prices. Evidence from green bonds. Journal of Banking and Finance, 98, 39-60.

Publisher's Note Springer Nature remains neutral with regard to jurisdictional claims in published maps and institutional affiliations. 